\title{
En fire år gammel jente med diaré, kraftsvikt og mutisme
}

\author{
En fire år gammel jente kom inn på sykehus med diaré, oppkast og feber. \\ Gastroenteritt hos barn er vanlig og regnes som ufarlig i industrialiserte \\ land. Vår pasient hadde i midlertid ledsagende kraftsvikt og mutisme, \\ og hennes gastroenteritt fikk et uvanlig forløp.
}

En fire år gammel tidligere frisk jente med norsk etnisk bakgrunn ble innlagt i sykehus på grunn av dehydrering, nedsatt allmenntilstand og slapphet. Hun hadde en tre dagers sykehistorie med oppkast, diaré og feber. Dagen før innleggelsen var talen blitt snøvlete, hun var ustø og klarte ikke å sitte oppreist. Innleggelsesdagen hadde hun sluttet å snakke og måtte bæres.

I akuttmottaket var det vanskelig å få kontakt med henne, men hun åpnet øyene når hun ble snakket til. Hun var nakkestiv og reagerte ikke på smertefulle prosedyrer. Pupillene var dilaterte, med symmetrisk reaksjon på direkte og indirekte lys. Hun hadde innsunkne øyne, tørre slimhinner og kjølige ekstremiteter. Det var normale funn ved klinisk unders $\varnothing$ kelse av hjerte, lunger og abdomen. Måling av vitale markører viste respirasjonsfrekvens 28/min (20-24/min), SpO $96 \%$, puls 103/min (70-120/min), kapillærfyllingstid 3 s (1-2 s) og temperatur $37,9^{\circ} \mathrm{C}$.

Kapillær blodprøve viste $\mathrm{pH}$ 7,35 (7,367,44), $\mathrm{pCO}_{2} 3,6 \mathrm{mmol} / \mathrm{l}(4,5-6,1 \mathrm{mmol} / \mathrm{l})$, base $-10 \mathrm{mmol} / \mathrm{l}(-3,0-3,0 \mathrm{mmol} / \mathrm{l}), \mathrm{HCO}_{3} 15$ $\mathrm{mmol} / \mathrm{l}(22-26 \mathrm{mmol} / \mathrm{ll})$, laktat $1,8 \mathrm{mmol} / \mathrm{l}$ (0,9-1,7 mmol/l), s-Na $135 \mathrm{mmol} / \mathrm{l}(137-145$ $\mathrm{mmol} / \mathrm{l}), \mathrm{s}-\mathrm{K} 5,2 \mathrm{mmol} / \mathrm{l}(3,5-5,0 \mathrm{mmol} / \mathrm{l})$ og s-glukose 4,6 mmol/l (4,0-6,0 mmol/l).

Infeksjonsmarkører viste $C R P<5 \mathrm{mg} / \mathrm{l}$ (normalt $<5 \mathrm{mg} / \mathrm{l}$ ), leukocytter $14,1 \cdot 10^{\%} / \mathrm{l}$ $\left(5,5-12,5 \cdot 10^{9} / l\right)$, nøytrofile granulocytter $12,1 \cdot 10^{9} / l\left(2,1-8,9 \cdot 10^{9} / l\right)$, lymfocytter 0,8 . $10^{9} / l\left(1,2-4,6 \cdot 10^{9} / l\right)$, monocytter $1,14 \cdot 10^{9} / l$ $\left(0,3-0,7 \cdot 10^{9} / 1\right)$

Jenta hadde metabolsk acidose med respiratorisk kompensasjon, milde elektrolyttforstyrrelser og normalt blodsukkernivå. Infeksjonsmarkørene var kun lett eleverte.

Tentativ diagnose initialt, ut fra feber, nedsatt bevissthetsnivå og nakkestivhet, var meningitt eller akutt encefalitt. Andre aktuelle årsaker til redusert eller svingende bevissthet kan være hypovolemi eller forgiftning. Hypoglykemi som årsak til nedsatt bevissthet ble tidlig utelukket.

Hun fikk væske intravenøst på grunn av mild dehydrering. Syre-base-forstyrrelsen og de milde elektrolyttforstyrrelsene rettet seg etter dette. Men rehydreringen førte ikke til at hun kom til normal bevissthet.

Det ble utført spinalpunksjon innleggelsesdagen, med resultat: leukocytter 268 . $106 / 1,90 \%$ polynukleære celler, erytrocytter $58 \cdot 106 / \mathrm{l}$, protein $0,76 \mathrm{~g} / \mathrm{l}(0,15-0,5 \mathrm{~g} / \mathrm{l})$, laktat 2,7 mmol/l $(<2,0 \mathrm{~g} / \mathrm{ll}$ og glukose 3,8 $\mathrm{mmol} / \mathrm{l}$. Det ble startet empirisk behandling med intravenøs cefotaksim og aciklovir mot intrakranial infeksjon.

Den neste dagen var jenta fortsatt stum og ga lite respons, bortsett fra at hun åpnet øynene. Hun kunne bevege hodet fra side til side, ellers var hun sengeliggende og beveget seg lite. Man observerte god hostekraft, og hun hadde ikke svelgevansker eller urinretensjon. Ved klinisk undersøkelse var inntrykket generell kraftnedsettelse i truncus og $i$ ekstremitetene. Senerefleksene var svake eller utslukket. Det var oppadvendt plantarsenerefleks venstre side og indifferent høye side. Pupillene var store og lysreaktive. Hun var ikke lenger nakkestiv.

Spinalvæsken hadde moderat forhøyede leukocytter på et nivå forenlig med både viral og bakteriell infeksjon. Det var grunnlag for å starte antibakteriell og antiviral behandling. Jenta fremviste vedvarende og alvorlige nevrologiske avvik. Differensialdiagnoser utover encefalitt var blant annet akutt inflammatorisk demyeliniserende polyradikulonevropati (Guillain-Barrés syndrom) og akutt demyeliniserende encefalomyelitt (ADEM) (1).

Guillain-Barrés syndrom debuterer ofte med nummenhet og parestesier i tær og fingertupper. Deretter blir det symmetrisk kraftsvekkelse i underekstremitetene. Vanlig er også smerter og gangvansker. Omtrent $50 \%$ får autonom dysfunksjon. Hjernenerveaffeksjon og respirasjonssvikt forekommer. Symptomene utvikler seg typisk over 2-4 uker. Spinalvæsken viser høyt proteintall og normal mengde hvite blodceller, men av og til ses karakteristiske spinalvæskefunn først etter 1-2 uker (1).

Ved akutt demyeliniserende encefalomyelitt er det rask utvikling av symptomene

\section{Mette Engan}

mette.engan@helse-bergen.no Barneklinikken

Haukeland universitetssykehus

John Asle Bjørlykke

Seksjon for barn

Radiologisk avdeling

Haukeland universitetssykehus

Gunnar Moen

Seksjon for nevroradiologi

Radiologisk avdeling

Haukeland universitetssykehus

Kjetil Børve Lund

Mikrobiologisk avdeling

Haukeland universitetssjukehus

Gro Njølstad

Mikrobiologisk avdeling

Haukeland universitetssykehus 


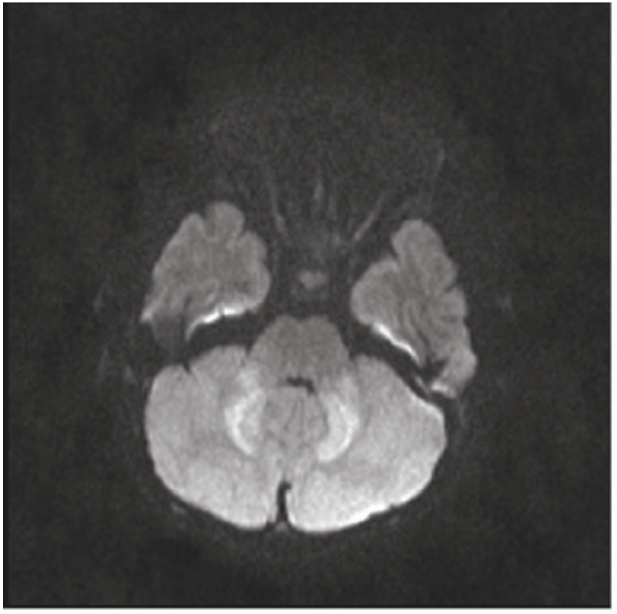

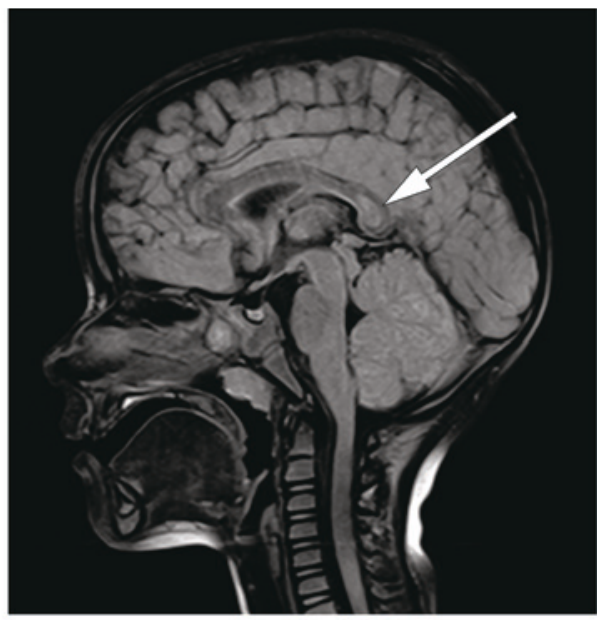

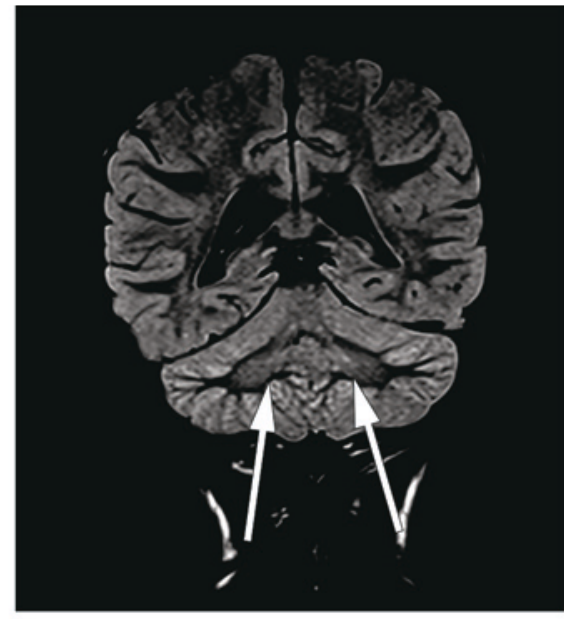

Figur 1 a) Aksial diffusjonsvektet sekvens ( $B=1$ 000) viser redusert diffusjon i området svarende til nucleus dentatus bilateralt. b) Sagittal FLAIR viser ødem i splenium corpus callosum. c) Koronal FLAIR viser ødem i område for nucleus dentatus bilateralt

(timer til få dager), som kan progrediere til koma. Sykdommen er multifokal med et vidt spekter av manifestasjoner. Økt hjernetrykk med risiko for herniering kan forekomme. Spinalvæsken viser ofte økt antall hvite blodceller og økt proteinnivå (1).

Det ble rekvirert MR cerebri på mistanke om akutt demyeliniserende encefalomyelitt. Denne viste redusert diffusjon i nucleus dentatus bilateralt $i$ cerebellum. Det var også lett signalavvik på T2-vektet sekvens i samme område. Tilsvarende signalavvik og diffusjonsavvik ble sett $i$ splenium corpus callosum. Ingen patologisk kontrastoppladning og intet annet patologisk ble påvist $i$ øvrige deler av hjernen.

I beskrivelsen av MR-undersøkelsen ble heteslag, bruk av metronidazol, virale infeksjoner, blant annet enterovirus, rotavirus og respiratorisk syncytialvirus, diskutert som mulige differensialdiagnoser til bildefunnet (fig 1).

Mutisme (stumhet) er assosiert med forandringer i lillehjernen og ses hos barn etter operative inngrep i bakre skallegrop. Ikke-kirurgisk cerebellær mutisme er sjeldent, men kan ses etter vaskulære hendelser, traume eller inflammasjon (2). Det er holdepunkter for at skade på nucleus dentatus og den dype grå substans i cerebellum bidrar til at mutisme oppstår. Forstyrrelser i den dentotalamokortikale bane spiller også en rolle $(2,3)$. Vår pasient hadde signalforandringer i nucleus dentatus bilateralt på MR. Dette kunne forklare hennes cerebellære symptomer med uklar tale og etter hvert stumhet før innleggelsen.

Pasienten vår hadde også symptomer på encefalitt med sløvhet. De sammenfallende encefalittsymptomene med signalavvik og diffusjonsavvik i splenium corpus callosum kunne passe med mild encefalopati med reversibel bakre hjernebjelkelesjon (mild encephalopathy with a reversible splenial lesion). Dette er et klinisk og radiologisk syndrom som hos asiatiske barn er beskrevet som en benign tilstand som ikke gir nevrologiske sekveler. Den har vært assosiert med ulike virus, som rotavirus, influensavirus, adenovirus og kusmavirus $(3,4)$.

De neste dagene kom det fortløpende svar på mikrobiologiske prøver. I avføringen ble det påvist rotavirusantigen i fire gjentatte prøver, senere også bekreftet med polymerasekjedereaksjon (PCR). Rotavirus ble $i$ tillegg isolert fra avføring og propagert $i$ cellekultur. Dyrkningsresultatet ble også bekreftet med antigentest og PCR. Øvrige mikrobiologiske analyser var negative. Jenta var ikke vaksinert mot rotavirus.

Etter MR-funn i cerebellum og splenium og funn av rotavirus $i$ avføringen ble diagnosen rotaviruscerebellitt stilt. I etterkant ble det utført PCR-undersøkelse av spinalvæsken, men rotavirusnukleinsyre ble ikke påvist. Rotavirusantigentest var også negativ.

Det er velkjent at rotavirus kan gi ulike nevrologiske symptomer, alt ifra harmløse krampeanfall til letal encefalopati/encefalitt $(5,6)$. I en svensk artikkel fra 2008 fant man at opp mot $4 \%$ av hospitaliserte med rotavirusinfeksjon fikk krampeanfall og 1,7\% fikk encefalitt (5).

Jenta hadde uvanlige symptomer med sløvhet, hypotoni og stumhet i forløpet av en rotavirusinfeksjon. Etter gjennomgang av MR-funn, symptomer og aktuell litteratur kom man frem til diagnosen rotaviruscerebellitt. Behandlingsstrategi ble drøftet - kortikosteroider, immunglobulin eller ingen behandling var alternativene.
Cerebellitt $\mathrm{i}$ forbindelse med rotavirusinfeksjon er tidligere beskrevet. Imidlertid er det kun få kasuistikker med kaukasiske barn der lignende sykdomstilfeller omtales (3, 4, 7-9). Det er blitt spekulert på om det foreligger en genetisk sårbarhet for tilstanden $\mathrm{i}$ asiatiske populasjoner $(10,11)$.

Takanashi og medarbeidere konkluderer i en retrospektiv studie fra 2010 at rotaviruscerebellitt har et særpreget sykdomsforløp med nedsatt bevissthetsnivå og cerebellær mutisme (4). Her beskrives 11 japanske barn i alderen 2-4 år med lignende symptomer som vår pasient - mutisme, encefalitt og hypotoni i forbindelse med rotavirusinfeksjon. Det var gjort MR-funn med forbigående signalavvik $\mathrm{i}$ corpus splenium og funn i cerebellums kjerner og cortex. Fem av de 11 barna ble behandlet med immunglobuliner og åtte fikk kortikosteroider. Etter en måned hadde ti av de 11 barna cerebellær atrofi på MR-undersøkelse. Åtte av de 11 barna hadde vedvarende nevrologiske avvik, hovedsakelig dysartri.

Fra USA er det rapportert om en tre og et halvt år gammel jente (etnisitet ikke beskrevet) med gastroenteritt, meningoencefalitt og funn av rotavirus i spinalvæsken (9). MR cerebri viste atrofi og diffuse endringer $i$ cerebellums grå substans bilateralt. Initialt hadde barnet uttalte cerebellære symptomer med ataksi, dysmetri og afasi. Etter ett år hadde hun fortsatt milde artikulasjonsvansker og milde finmotoriske vansker. Nevropsykologisk vurdering etter 14 måneder viste normal kognitiv funksjon.

En belgisk jente på to og et halvt år hadde nedsatt bevissthet og stumhet. MR cerebri viste en forbigående lesjon i splenium og samtidig diffusjonsendring i høyre nucleus dentatus. Hun ble initialt behandlet med aciklovir intravenøst etter funn av mild pleo- 
cytose i spinalvæsken. Influensavirus type A ble påvist $\mathrm{i}$ nasopharynxprøve. Etter en måned var det ingen sekveler (11).

I to andre rapporter omtales til sammen åtte barn av kaukasisk opprinnelse med forbigående lesjon i splenium sammen med encefalitt. Ulike infeksiøse agenser ble påvist (cytomegalovirus, influensa B-virus, adenovirus, rotavirus og Salmonella). Disse fikk behandling med kortikosteroider $(10,12)$.

Fra 4. innleggelsesdag hadde vår pasient normal bevissthet, men hun var fortsatt hypoton og sengeliggende. De cerebellære symptomene med mutisme og dysmetri ble mer fremtredende. Hun kunne le og beveget seg mer i sengen, men hadde ukoordinerte og upresise bevegelser. Det ble tatt EEG for å se etter encefalittforandringer. Denne var normal for alderen.

6. innleggelsesdag ble det startet med prednisolon $2 \mathrm{mg} / \mathrm{kg} /$ døgn i 14 dager, deretter nedtrapping de neste fire ukene. Hun fikk fysioterapi daglig. Etter to ukers sykdom kunne hun sitte uten støtte. Hun hadde avtagende dysartri og forsøkte å snakke $i$ hele setninger. Det ble anskaffet rullestol og gåstativ.

Seks måneder ut i forløpet var talen fortsatt langsom og monoton, og hun hadde vansker med finmotoriske oppgaver. Hun ble fort trett og var derfor ikke i barnehagen på fulltid. Det ble reist spørsmål om konsentrasjonsvansker. Nevropsykologisk testing kan bli aktuelt før skolestart. Samlet sett hadde hun hatt en langsom bedring, men det var vedvarende nevrologiske sekveler.

\section{Diskusjon}

Vår pasient hadde, til å være av kaukasisk opprinnelse, et svært sjeldent klinisk bilde og uvanlige MR-funn. Radiologisk og mikrobiologisk diagnostikk var helt vesentlig for å stille diagnosen. Sykdomsforløpet passet godt med det Takanashi og medarbeidere beskriver som et sykdomsforløp særegent for rotaviruscerebellitt. Hittil er det kun få rapporter om cerebellitt og mild encefalopati med reversibel bakre hjernebjelkelesjon i forbindelse med virale infeksjoner hos kaukasiske barn. Kanskje foreligger det en genetisk eller miljømessig predisposisjon i den asiatiske befolkningen?

Noen spesifikk anbefalt behandling ved rotaviruscerebellitt foreligger ikke. Denne pasienten ble behandlet med prednisolon i forsøk på å dempe en antatt inflammatorisk prosess. Vi vet ikke om behandlingen lindret symptomene eller om dette var sykdommens naturlige forløp. Langtidsprognosen er usikker, siden tilstanden ikke er godt beskrevet. Det har til nå ikke vært indikasjon for ny MR-undersøkelse siden det ikke vil ha behandlingsmessige konsekvenser.

Hvordan en rotavirusinfeksjon kan påvirke sentralnervesystemet uten en direkte invasjon, er ikke avklart (13). Det har vært noen rapporter om funn av rotavirus-RNA i spinalvæsken hos pasienter med cerebrale symptomer i forløpet av en rotavirusenteritt $(9,14$, 15). I denne sammenhengen er det interessant at rotavirusvaksinering ser ut til å føre til færre sykehusinnleggelser grunnet krampeanfall hos barn (16). Det gjenstår å finne ut om rotavirusvaksinering også beskytter mot rotavirusencefalitt.

Pasientens foreldre har gitt samtykke til at artikkelen blir publisert.

\section{Mette Engan (f. 1979)}

er spesialist i barnesykdommer.

Forfatter har fylt ut ICMJE-skjemaet og oppgir ingen interessekonflikter.

\section{John Asle Bjørlykke (f. 1970)}

er spesialist i radiologi.

Forfatter har fylt ut ICMJE-skjemaet og oppgir ingen interessekonflikter.

\section{Gunnar Moen (f. 1958)}

er overlege.

Forfatter har fylt ut ICMJE-skjemaet og oppgir ingen interessekonflikter.

\section{Kjetil Børve Lund (f. 1986)}

er bioingeniør med mastergrad. Han er fagansvarlig for virusdyrkning i cellekultur ved Mikrobiologisk avdeling.

Forfatter har fylt ut ICMJE-skjemaet og oppgir ingen interessekonflikter.

\section{Gro Njølstad (f. 1957)}

er spesialist i medisinsk mikrobiologi og i pediatri, seksjonsoverlege ved Virologisk seksjon og medlem av Referansegruppe for ekstern kvalitetssikring i virologi og serologi. Forfatter har fylt ut ICMJE-skjemaet og oppgir ingen interessekonflikter.
Litteratur

1. Døllner H, Bjurulf B, Klingenberg C. Akuttveilederen i pediatri, versjon 3, 2013: Serøs meningitt, akutt encefalitt og akutt disseminerende encefalomyelitt (ADEM). www.helsebiblioteket.no/ retningslinjer/akuttveileder-i-pediatri/infeksjoner/ seros-meningitt (15.10.2015).

2. Küper M, Timmann D. Cerebellar mutism. Brain Lang 2013; 127: 327-33.

3. Mori T, Morii M, Kuroiwa Y et al. Rotavirus encephalitis and cerebellitis with reversible magnetic resonance signal changes. Pediatr Int 2011; 53: $252-5$

4. Takanashi J, Miyamoto T, Ando N et al. Clinical and radiological features of rotavirus cerebellitis. AJNR Am J Neuroradiol 2010; 31: 1591-5.

5. Johansen K, Hedlund KO, Zweygberg-Wirgart B et al. Complications attributable to rotavirus-indu ced diarrhoea in a Swedish paediatric population: report from an 11-year surveillance. Scand J Infect Dis 2008; 40: 958-64.

6. Kawamura Y, Ohashi M, Ihira M et al. Nationwide survey of rotavirus-associated encephalopathy and sudden unexpected death in Japan. Brain Dev 2014; 36: 601-7.

7. Kato Z, Sasai H, Funato M et al. Acute cerebellitis associated with rotavirus infection. World J Pediatr 2013; 9: 87-9

8. Nigrovic LE, Lumeng C, Landrigan $C$ et al. Rotavirus cerebellitis? Clin Infect Dis 2002; 34: 130.

9. Dickey M, Jamison L, Michaud L et al. Rotavirus meningoencephalitis in a previously healthy child and a review of the literature. Pediatr Infect Dis J 2009; 28: 318-21.

10. Ka A, Britton P. Troedson C et al. Mild encephalopathy with reversible splenial lesion: an importan differential of encephalitis. Eur J Paediatr Neurol 2015; 19: 377-82

11. Fluss J, Ferey S, Menache-Starobinski C et al. Mild influenza-associated encephalopathy/encephalitis with a reversible splenial lesion in a Caucasian child with additional cerebellar features. Eur J Paediatr Neurol 2010; 14: 97-100

12. Mazur-Melewska K, Jonczyk-Potoczna K, Szpura $K$ et al. Transient lesion in the splenium of the corpus callosum due to rotavirus infection. Childs Nerv Syst 2015; 31: 997-1000

13. Incecik F, Hergüner MO, Altunbaşak $S$ et al. Acute encephalopathy associated rotavirus gastroenteritis. J Pediatr Neurosci 2009; 4: 141-3

14. Arakawa C. Fujita Y, Imai Y et al. Detection of group a rotavirus RNA and antigens in serum and cerebrospinal fluid from two children with clinically mild encephalopathy with a reversible splenial lesion. Jpn J Infect Dis 2011; 64: 204-7.

15. Lynch M, Lee B, Azimi P et al. Rotavirus and central nervous system symptoms: cause or contaminant? Case reports and review. Clin Infect Dis 2001: 33: 932-8.

16. Sheridan SL, Ware RS, Grimwood K et al. Febrile Seizures in the Era of Rotavirus Vaccine. J Pediatric Infect Dis Soc 2016; 5: 206-9.

Mottatt 28.1. 2016, første revisjon innsendt 15.5 2016, godkjent 23.6. 2016. Redaktør: Martine Rostadmo. 